日臨外会誌 $61 （ 6), 1520-1524,2000$

症例

切除血行再建術により治癒せしめた固有肝動脈瘤の 1 例

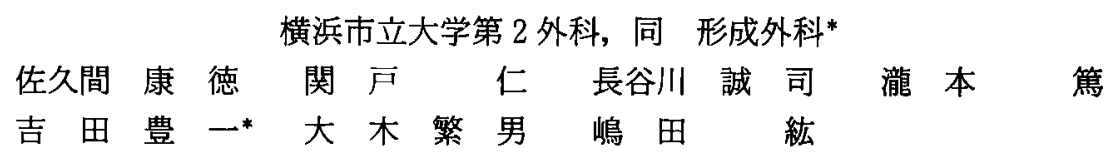

症例は72歳, 女性. 上行結腸癌術前のCT て固有肝動脈起始部から左右肝動脈分岐部 直前にかけて存在する固有肝動脈瘤が偶然に発見された．塞栓療法を施行する予定だっ たが, 操作中破裂の危険性があると判断し固有肝動脈瘾切除, 血行再建術を施行した. 動脈は左右肝動脈分岐部より末梢で, 中枢側は総肝動脈, 胃十二指腸動脈で切離し, 血 行再建は右肝動脈, 胃十二指腸動脈を端々吻合にて行った。術後ドップラーエコーで肝 への血流は良好で血液検査上肝機能障害はなく，また血管造影でも吻合部狭窄を認めず， 経過は良好であった。現在, 肝動脈瘤の治療法として動脈瘤塞栓術の適応も増加してい るが，動脈瘤はその最大径に関わらず破裂する頻度が高く致命的であるため，切除可能 な部位であれば発見次第外科的切除を行うのが望ましいと思われた。

索引用語：肝動脈瘤, 腹部内蔵動脈瘤, 血行再建

\section{緒言}

腹部内臓動脈瘤のうち, 比較的稀な固有肔動脈瘤に 対し，切除端々吻合による再建を行い治癒せしめた症 例を経験したので，文献的考察を加え報告する.

$$
\text { 症例 }
$$

症例: 72歳, 女性.

主訴：CT scanで肝門部に腫瘤を指摘された。自覚 症状なし.

家族歴：特記すべきことなし。

既往歴：40歳代加高血圧，69歳加糖尿病を指摘 されている。

現病歴：平成 6 年 4 月 21 日上行結腸癌の診断で当科 に入院, 右半結腸切除術を施行された. その際, 術前 CTで肝下面に造影効果のある径 $2.5 \times 2.3 \mathrm{~cm}$ の類円 形の腫瘤を認め, 動脈瘤が疑われた。血管造影にて固 有肝動脈瘤と診断され，以降 CT, エコーにて経過観察 していたが，平成 9 年 5 月 22 日の CT で動脈瘤の増大 が認められたため, 切除目的で入院した。

入院時現症: 身長 $147 \mathrm{~cm}$, 体重 $62.5 \mathrm{~kg}$, 血圧 $178 / 94$ $\mathrm{mmHg}$, 脈拍 $68 /$ 分, 眼球結膜, 目瞼結膜ともに貧血, 黄疸を認めず.腹部は平坦で腫瘤は触知せず, 自発痛, 圧痛なく，血管雑音は聴取しなかった。下血の既往も

1999年 5 月 12 日受付 2000 年 3 月21日採用
なかった.その他，理学的異常所見は認めなかった。

入院時検査所見 : WBC $4600 / \mathrm{mm}^{3}, \mathrm{RBC} 408 \times 10^{4} /$ $\mathrm{mm}^{3}$, Hb $13.3 \mathrm{~g} / \mathrm{dl}$, Ht $39.6 \%$, Plt $15.8 \times 10^{4} / \mathrm{mm}^{3}$, GOT 16IU, GPT 14IU, $\gamma$-GTP $44 \mathrm{mu} / \mathrm{ml}$, T-bil 0.7 $\mathrm{mg} / \mathrm{dl}$, D-bil 0.1mg/dl, T. chol $246 \mathrm{mg} / \mathrm{dl}$, Glu 119 $\mathrm{mg} / \mathrm{dl}, \mathrm{Hb}-\mathrm{Alc} 5.9 \%$ と, 肝機能障害は認めず, $\mathrm{T}$. chol, Glu, Hb-Alc が軽度上昇しているのみであっ た．梅毒反応は陰性であった。

血管造影所見：平成 8 年 3 月 4 日固有肝動脈に内腔 $25 \times 29 \mathrm{~mm}$, 頸部は約 $25 \mathrm{~mm}$ の動脈瘤を認めた. 瘤の根 部は固有肝動脈起始部約 $3 \mathrm{~mm}$ からはじまり, 左右肝 動脈分岐直前まで続いていた（図 1 )。当初，バルーン で総肝動脈の分岐部をクランプし側副血行を確認した 後, 動脈瘤にコイリングを行う予定であったが, 巨大 動脈瘤のため動脈瘤径に合致するコイルはなく，かつ 操作中に破裂する可能性, コイルの目的外への流入逸 脱などの危険性を考慮し, 造影のみで終了した。

手術所見：固有肝動脈瘤の診断のもと平成 9 年 5 月 27日固有肝動脈瘤切除衍, 血管再建術を施行した。 ず胆摘を行った後, 肝十二指腸間膜内に径約 $4 \mathrm{~cm}$ の 動脈瘤を確認した．動脈瘤の壁は肥厚していたが比較 的弾性が保たれており，拍動を認めた。瘤は周囲組織 に軽度撚着していたが, 容易に剥離が可能だった。瘤 が固有肝動脈起始部から左右肝動脈分岐部の prox- 


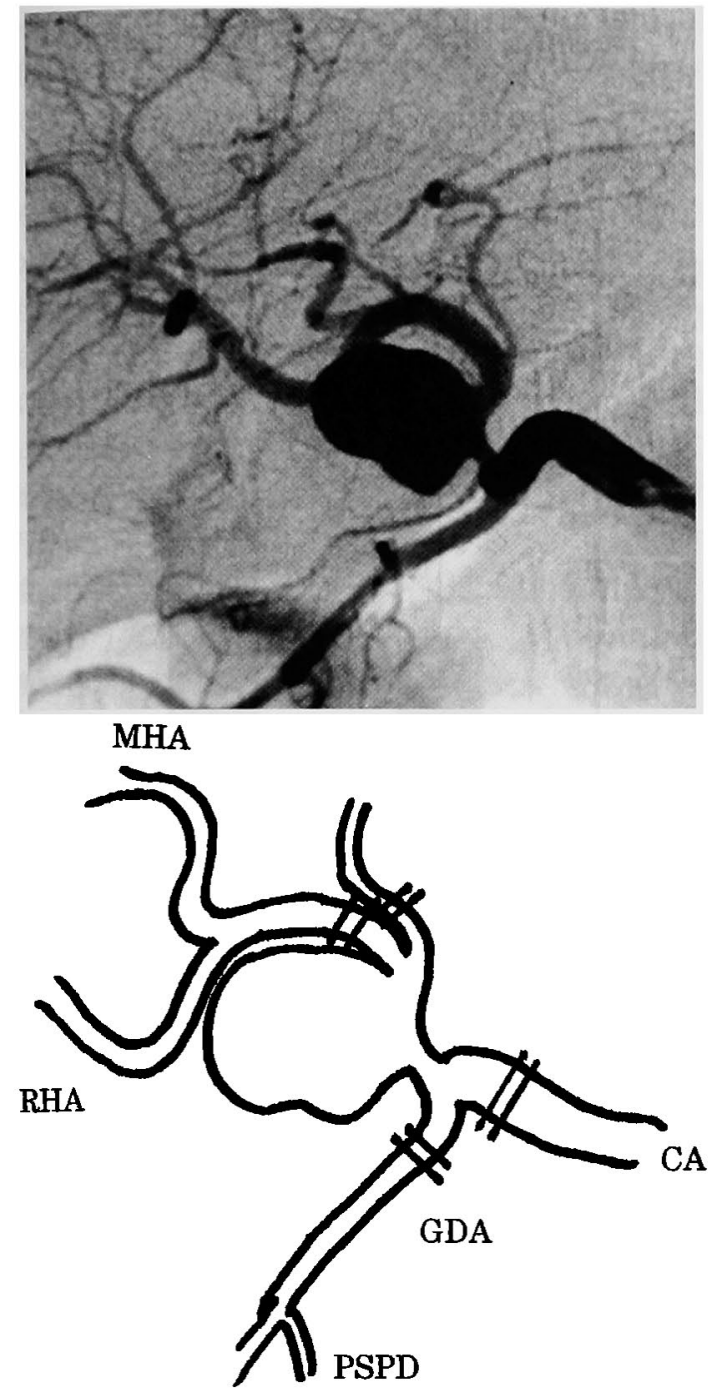

図 1 術前 腹腔動脈からの血管造影写真とそのシェー マ: 固有肝動脈起始部に灌状動脈瘤を認める.

imal 0.5cm にかけて存在しているのを確認後, 末梢側 は左右肝動脈分岐後で切離, 中枢側は総肝動脈, 胃十 二指腸動脈で切離した．左肝動脈のクランプを一時的 に解除し，拍動性の出血により側副血行があることを 確認した後, 左肝動脈, 総肝動脈は結禁した。血行再 建は, 右肝動脈と胃十二指腸動脈の端々吻合で行った。 縫合はルーペ下に 7-0Prolene を用いて行った．肝血 流を維持するために術直後より PGE1を $500 \mu /$ 日を POD2 まで持続注入し, POD3 から POD8 まで60 $\mu \mathrm{g} \times$ 2/日にて使用した.へパリンなど抗凝固剂は用いなか った.
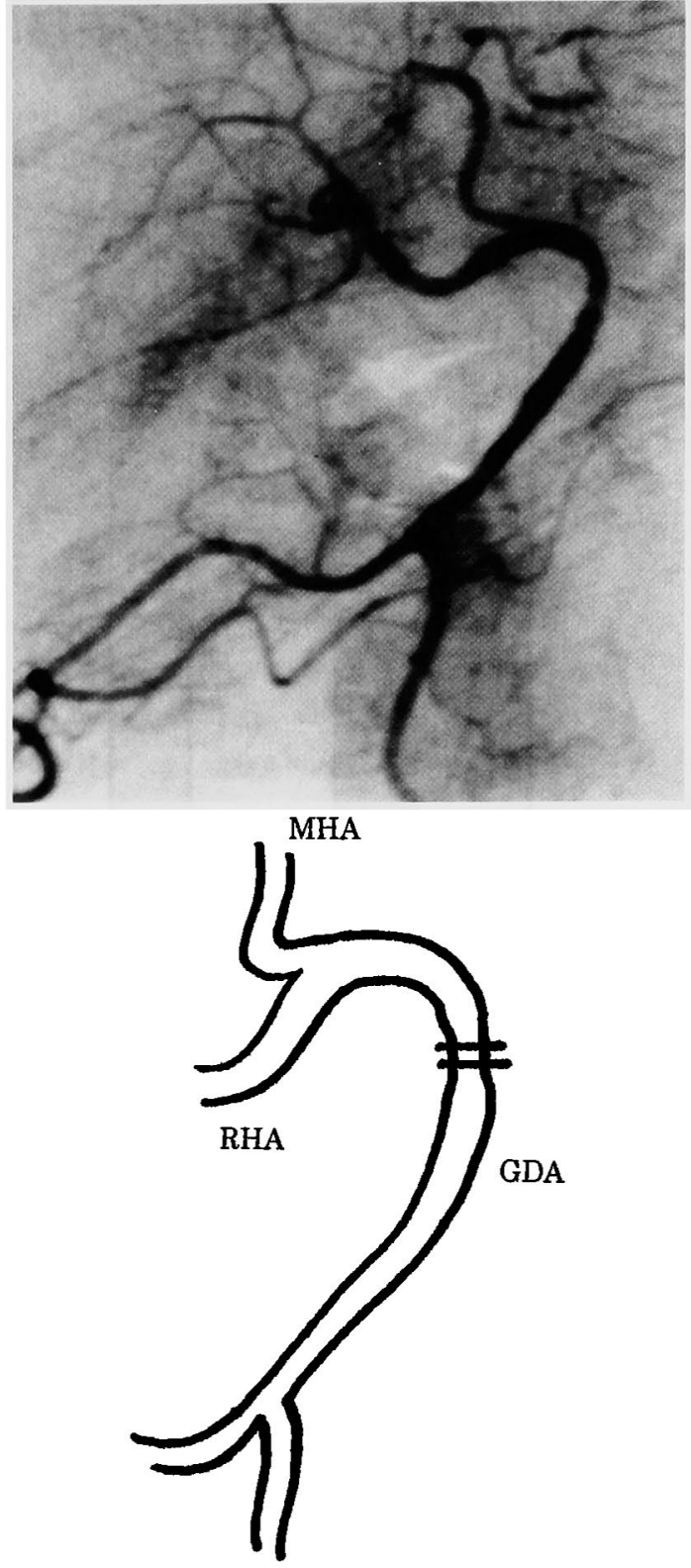

図 2 術後 上腸間膜動脈からの血管造影：側副血行路 を介して右，中肝動脈が造影されている，吻合部に狭 窄やリークは認めない.

病理診断：動脈瘤は大きさ $3.0 \times 2.7 \times 3.2 \mathrm{~cm}$ で, 肉 眼的には白色調の内膜を持ち, 壁の肥厚と内腔に血栓 を認めた。組織学的には䉼腫と器質化した血栓で，血 管炎の所見は認められず，動脈硬化性動脈瘤と診断さ れた。

術後経過：ドップラーエコーにおいて右肝動脈の血 


\section{動脈瘤最大径と破裂の有無}

\section{動脈瘤破裂例の成因別検討}

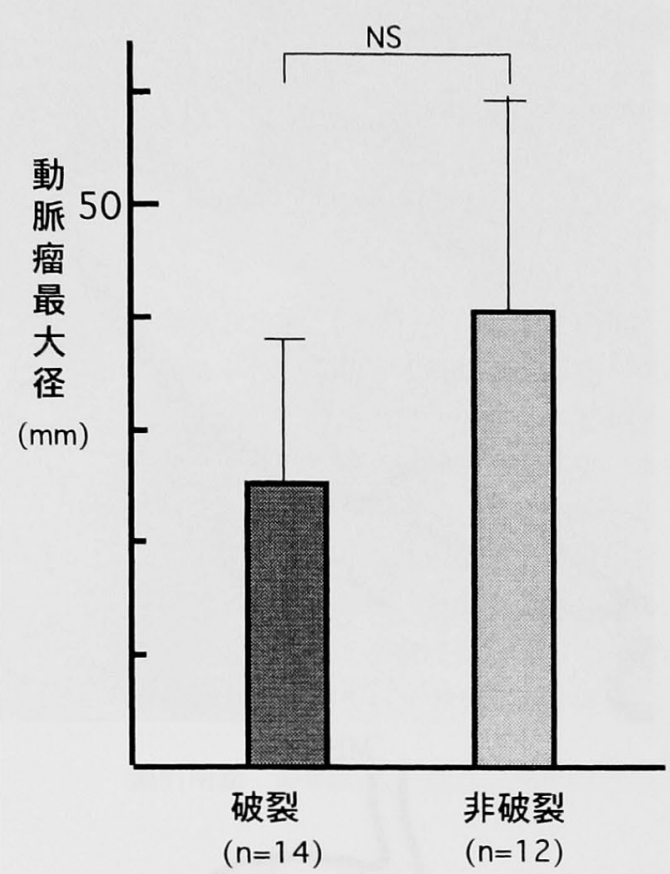

(a)

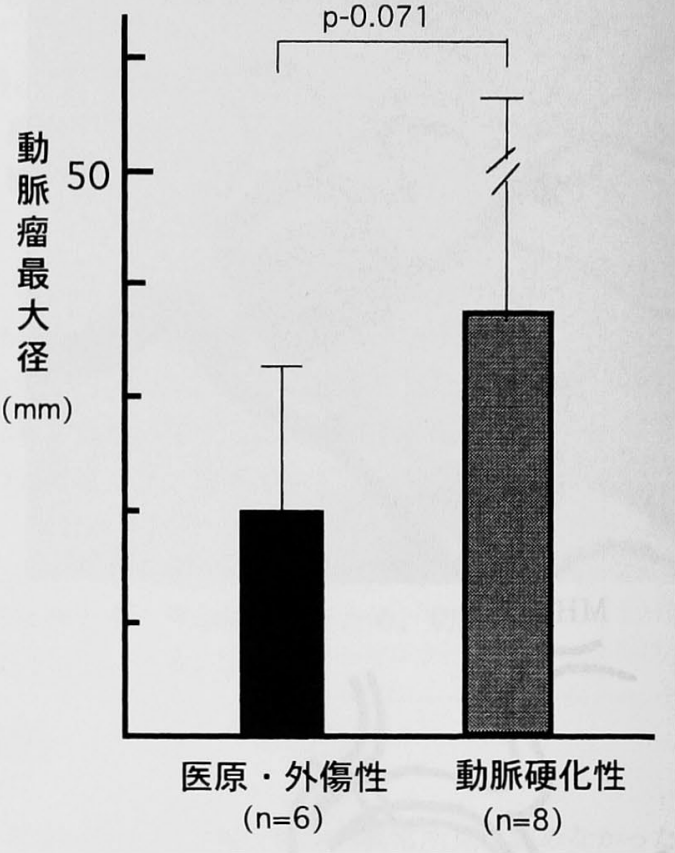

(b)

図 $3 x^{2}$ test $\mathbf{p}<0.05 ：(a)$ 破裂と非破裂の動脈瘤の最大径について，両者の間に有意差はなかった，

(b) 破裂した動脈督について主要な成因別にその最大径の比較でも，明かな有意差は認められなかった。

流は良好で, 左肝動脈末梢の血流も十分に確認された。 6 月 9 日退院するまでビリルビン，トランスアミナー ゼの上昇はなく，全身状態は良好であった。

術後血管造影所見: 平成 9 年 8 月 27 日, 術後約 3 力 月目に血管造影を施行した。肝への血流はSMA $\rightarrow$ $\mathrm{PSPDA} \rightarrow \mathrm{GDA} \rightarrow \mathrm{RHA} / \mathrm{MHA}$ の経路で良好に造影 された，吻合部からの造影剤の漏出や，吻合部の狭窄， 血流障害は認めなかった（図 2 ）。

$$
\text { 考察 }
$$

腹部内藏動脈瘤は現在までに 2800 例以上の報告があ $\eta^{11}$, 性別では 2：1 で男性, 60歳以上が好発年齢であ る ${ }^{2)}$. 1970年には Deterling ${ }^{3)}$ が1424例の文献的集計を 行っており，その中でも肝動脈瘤は16\%，230例を占め るにすぎない．また収集可能な肝動脈瘤の本邦報告例 は，1962年の畠山らの報告 ${ }^{4}$ 以来自験例を含めて 107 例 で，固有肝動脈瘤に限るとさらに少なく21例である。 発生部位別頻度総肝 $(34.6 \%)$, 右肝 $(25 \%)$, 固有 肝 $(23.1 \%)$, 左肝 $(13.5 \%)^{5)}$ の順である.

肝動脈瘤の原因としては, 外傷 $(28.8 \%)$, 記載なし
(28.8\%)，動脈硬化 (21.2\%)，炎症 (11.5\%)，細菌 性 (7.7\%) という報告があるが，最近では血管造影施 行後や拉大根治手術後など医原性の動脈瘤が增加の傾 向にあり，今後更に増加すると思われる、また，肝動 脈瘤の破裂率は $44 \%{ }^{6}$ ) と高く（高橋らによると60～ 80 \%), 医原性, 細菌性の動脈溜ではさらに高率で $80 \%$ 以 上7), 破裂時死亡率は50\%を越えるため ${ }^{8)}$, 頻度は少な い疾患ながらも常に頭の片隅に留めておかなくてはな らない. 今回, 詳細の明らかな本邦報告肝動脈瘤26例 について大きさと破裂との関係を検討したところ，両 者の間に相関関係は認められなかった（図3）.

肝動脈瘤破裂により右季肋部痛, 黄疸, 消化管出血 の三徴を呈することが知られているが, 無症状で経過 することも多く, Busuttil ら 症状であったと報告している，さらにこの三徴がそろ うのは30\%にすぎず，確定診断がつかないまま開腹後 発見される事もあるが, 最近では CT, 腹部超音波検査 で偶然発見されることが多い.

治療：治療法は大きく分けて動脈瘤切除術と経力テ 
ーテル動脈瘤塞栓術（TAE）の 2 通りがある．技術の 進歩と共にカテーテル動脈濾塞恮術の適応は增えてき ているが，外科的治療が中心なのは翂わりない.

TAE の適応は外科的切除が困難である肝内動脈瘤 や，破裂例での緊急止血, 周囲の炎症や癒着, 動脈壁 が脆弱など手術が困難な場合がよい適応だが5)10)，今 回の症例のように肝外の非破裂動脈瘤では, 動脈瘤切 除を第一選択として考えてよいだろう。手術法として 切除, 結禁㿔空置によるものが大部分であるが，一部 には血行再建術が必要となる．固有肝動脈瘤では瘤切 除後, 肝への血流は門脈, 右横隔膜下動脈など側副血 行路により維持されるという意見もあるようだが，肝 機能保持, 胆管壊死や肝膿場を未然に防ぐため血行再 建を行う方が安全であろう。その他にも血管分岐には 多样性があり, 切除部位によっては血行再建を必要と する場合があるため, 術前に血管造影は必要不可欠で ある。また，総肝動脈瘤では総肝動脈より末梢側へ胃 十二指腸動脈からの側副血行があるため㿔切除結絷 を, 左右肝動脈痹では肝実質内で左右肝動脈に交通が あるためどちらか一方を切離結势しても肝への血流は 問題ない"11).再建にも大伏在静脈グラフトを用いた方 法，脾動脈を反転させ用いる方法など様々だが，この 症例では胃十二指腸動脈を容易に挙上でき, さらに動 脈内腔径は右肝動脈が $3 \mathrm{~mm}$, 胃十二指腸動脈が $4 \mathrm{~mm}$ と十分に端々吻合可能と判断しこれを行った。

\section{結語}

腹部動脈瘤のなかで比較的稀な固有肝動脈瘤の 1 例 を報告した。肝動脈瘤はその大きさに関わらず，破裂 する危険性が高いため，発見次第確実な外科的治療を 行うべきである．また，血管外科手術手技の進歩によ り動脈吻合が安全確実になった現在, 固有肝動脈瘤に おいても動脈瘤切除血行再建術を積極的に行うのが望
ましいと考えられた。

文献

1）佐藤典宏, 上田祐滋, 豐田清一他：緊急手術によ り救命し得た右胃大網動脈瘁破裂の 1 例。日臨外 医会誌 $56 ： 1619-1623 ， 1995$

2) Stanley JC: Splanchnic artery aneurysms. In Rutherford RB (ed), Vascular Surgery. Saunders, Philadelphia, 1977, p673-685

3) Deterling RA:Aneurysm of the visceral arteries. J Cardic Surg 12:309-322, 1971

4）畠山靖夫, 宇留賀一夫, 安田恒夫：閉塞性黄疸の 原因となり後に胆道内破裂をきたした肝動脈瘤の 一例. 東北医誌 $65 ： 344-353 ， 1962$

5）森田 穣, 斉藤博哉, 広村忠雄：腹部内臟器（腎 を除く)動脈溜に対する経動脈カテーテルル塞栓術。 眽管学 $28: 61-69,1988$

6）稲田 潔, 廣瀬光男：末梢血管の疾㭧。金原出版, 東京， $1987, \mathrm{p} 144-148$

7) 高橋美香子, 中野 哲, 武田 功他: 離脱式コイ ルが有効であった肝動脈瘤 TAEの一例．臨放線 $40: 621-624,1995$

8) Smyth NPD and Teimourian B : Resection of hepatic arterial aneurysm following intraperitoneal rupture. Ann Surg $160: 61-70,1964$

9) Busuttil RW, Brin BJ: The diagnosis and management of visceral artery aneurysm. Surgery $88: 619-624,1980$

10）森田 穣, 斉藤博哉, 安友紀幸：肝動脈㵌に対す る経カテーテル動脈塞栓術。肝臓 $30 ： 477-483$, 1989

11）下沢英二, 高橋利幸, 道家 充: 膵・胆道外科に 抢ける血行再建の工夫。手術 $49 ： 665-674,1995$ 


\title{
SUCCESSFUL VASCULAR RECONSTRUCTION AFTER RESECTION OF PROPER HEPATIC ARTERIAL ANEURYSM IN ONE PATIENT
}

\author{
Yasunori SAKUMA, Hitoshi SEKIDO, Seiji HASEGAWA, Atushi TAKIMOTO, \\ Toyokazu YOSHIDA*, Shigeo OOKI and Hiroshi SHIMADA \\ Second Department of Surgery, Yokohama City University School of Medicine \\ *Department of Plastic Surgery, Yokohama City University School of Medicine
}

\begin{abstract}
A 72-year-old woman was found to have a proper hepatic arterial aneurysm on CT scan for preoperative evaluation of ascending colon cancer. Follow-up CT scan confirmed the aneurysm's enlargement. Transcatheter arterial embolization (TAE) for the aneurysm was not performed because of risk of rupture. Resection of the aneurysm was completed with right and left hepatic arteries on the distal side, and common hepatic and gastroduodenal arteries on the proximal side. After ligation of the left and common hepatic arteries, the right hepatic artery was anastomosed to the gastroduodenal artery for hepatic arterial reconstruction. Postoperative doppler ultrasonography showed adequate blood flow to the right hepatic artery. The postoperative hematological examination demonstrated no severe hepatic injury. Three months later, angiography showed patency of the anastomotic site with no stenosis. Although the incidence of performing TAE for hepatic arterial aneurysm has been increasing, there was significant risk of rupture during this procedure. Resection of the aneurysm is thought to be the optional treatment for this disease.
\end{abstract}

